\title{
ELECTROPHORETIC AND IMMUNOLOGICAL STUDIES ON SERA FROM CALVES FROM BIRTH TO WEANING
}

\author{
II. ELECTROPHORETIC AND SEROLOGICAL STUDIES WITH SPECIAL \\ REFERENCE TO THE NORMAL AND INDUCED AGGLUTININS TO \\ TRICHOMONAS FOETUS
}

\author{
By A. E. PIERCE \\ A.R.C. Institute of Animal Physiology, Babraham, Cambridge
}

(With 8 Figures in the Text)

\section{CONTENTS}

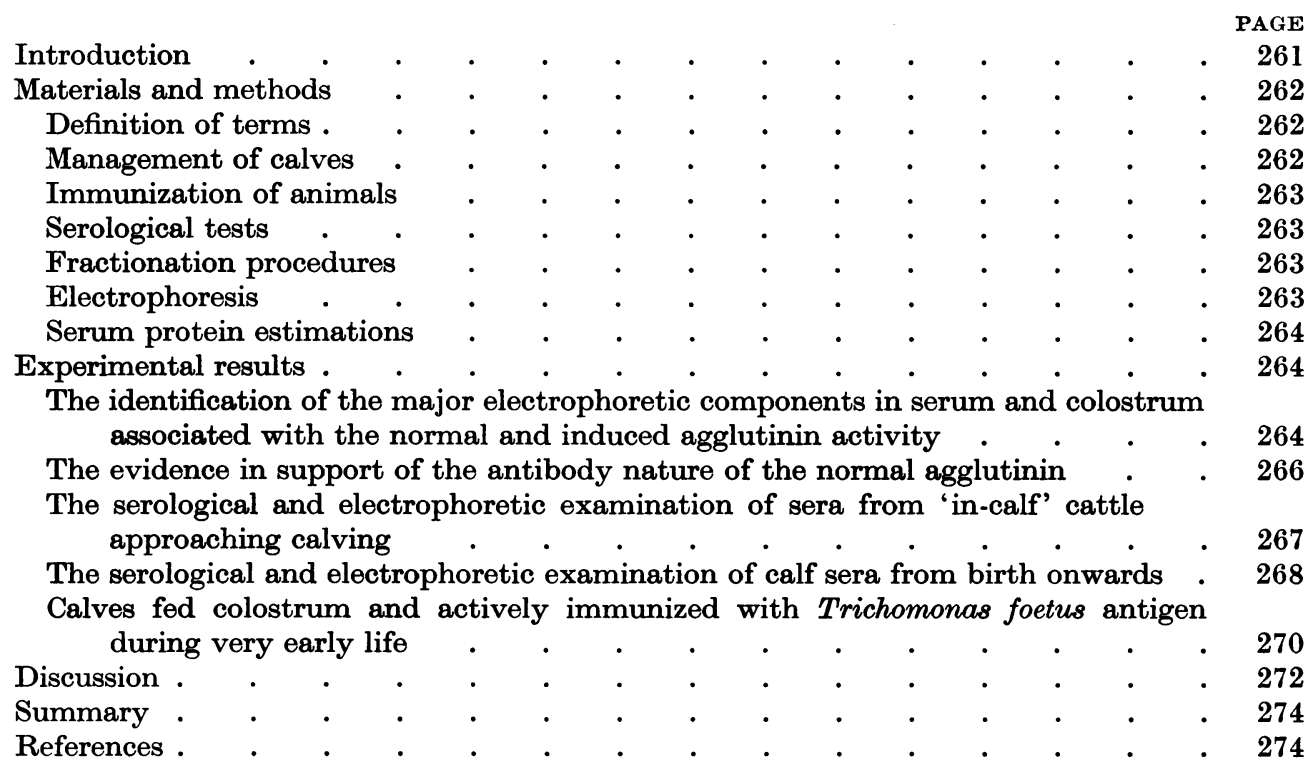

\section{INTRODUCTION}

The passive acquisition of colostral globulin is an important factor in the survival of the neonatal calf (Aschaffenberg, 1949). Immune globulins are unable to pass the placenta in significant amounts, and the calf acquires after birth from the ingested colostrum of the dam a wide range of antibodies. This is a normal physiological process, which operates in the first $24 \mathrm{hr}$. The ingested immune lactoglobulins are taken up by the cells of the epithelium of the small intestine, pass into the lymph spaces and then into the blood circulation by way of the thoracic duct (Comline, Roberts \& Titchen, $1951 a, b$ ).

Previous investigations by Kerr \& Robertson $(1941,1943)$ have shown the presence of two agglutinins to Trichomonas foetus, a naturally occurring agglutinin (normal agglutinin, see below) which is present in the serum of all adult cattle, and an induced agglutinin which develops as the result of natural infection or the injection 
of trichomonas antigen. Since both these agglutinins are passively transferred in the colostrum to the neonatal calf (Kerr \& Robertson, 1946, 1954) there was an opportunity for studying differences in their behaviour and characteristics. It is also an advantage that the disease is strictly venereal, so that calves may readily be isolated from chance infection.

$T$. foetus is a protozoon parasitic in cattle, causing infertility and abortion, and in this group of pathogens no similar investigation has been attempted. The organism can be grown in bulk and in sterile culture so that antigen was available for immunization and in vitro serological studies. There are two serological varieties of $T$. foetus (Kerr \& Robertson, 1945) strain Belfast $(B)$ and Manley $(M)$ which produce clinically identical diseases. Both strains are agglutinated by the naturally occurring agglutinin to approximately the same titre. Specific induced agglutinins, on the other hand, provided the animals are not hyperimmunized, are specific for the $M$ or $B$ strain (Kerr \& Robertson, 1954). Duplicate tests, therefore, using in one $B$ and the other $M$ strain enable the titre of the normal agglutinin to be independently determined when the induced and the naturally occurring agglutinin co-exist.

The present investigation confirms and extends previous serological studies of Kerr \& Robertson and includes the electrophoretic examination of the serum and colostral proteins associated with these antibodies.

\section{MATERIALS AND METHODS}

\section{Definition of terms}

'Normal agglutinin', the naturally occurring agglutinin to $T$. foetus present in the serum of all adult cattle, in the absence of specific immunization or infection with $T$. foetus.

'Induced agglutinin', the agglutinin which develops as the result of artificial immunization with $T$. foetus.

'Autogenous normal agglutinin' describes the development of the normal agglutinin in the young calf without the injection of $T$. foetus antigen (Kerr \& Robertson, 1954).

'Passive agglutinin' or 'passive globulin', the agglutinin, normal and induced, or globulin acquired passively by the neonatal calf following the ingestion of colostrum from a normal or immunized dam.

'Lacto-globulin', refers to the slowest electrophoretic component in colostral whey and is the globulin associated with antibody activity (Pierce, 1955).

The term 'antibody' has been avoided in referring to the normal agglutinins since neither the stimulus to their production nor their chemical identity are known.

\section{Management of calves}

Shorthorn or shorthorn-cross calves were removed from their dams at birth. The general management of the calves has been described by Pierce (1955). Electrophoretic examinations were made on serial samples of serum from four dams approaching calving, six calves in the colostrum-fed group, two of which were 
immunized, and four in the colostrum-deprived group. The latter were fed either a limited amount of colostrum or were given lacto-globulin prepared from colostrum fractionated with $\mathrm{Na}_{2} \mathrm{SO}_{4}$ (see Pierce, 1955).

The serological examination was carried out on a larger group of calves. The additional results, however, yielded no new information, and served only to confirm the findings on sera from the calves which were also examined electrophoretically; they have not therefore been included.

\section{Immunization of animals}

The dams and calves were immunized by the intramuscular injection of whole $T$. foetus organisms either freeze-dried or acetone-dried. The bulk growth of the organism and the preparation of the antigen have been described by Kerr \& Robertson (1953).

\section{Serological tests}

The agglutinin titres for $T$. foetus were determined by the method of Kerr \& Robertson using suspensions of the live organisms (Kerr \& Robertson, 1941; Pierce, 1947) and sera heated to $56^{\circ} \mathrm{C}$. for $18 \mathrm{~min}$.

The agglutination titre was the highest dilution at which the organisms appeared in small compact clumps. Higher dilutions at which the organisms were loosely attached by their flagella were ignored.

\section{Fractionation procedures}

The serum proteins were fractionated with $\mathrm{Na}_{2} \mathrm{SO}_{4}$ (Kekwick, 1940 ; Kekwick \& Record, 1941) with ethanol (Hess \& Deutsch, 1948, 1949) and with ether (Kekwick \& Mackay, 1954) to determine which of the major electrophoretic components were associated with the normal and induced agglutinin. The colostral whey from which the casein had been removed by precipitation with rennin was fractionated with $\mathrm{Na}_{2} \mathrm{SO}_{4}$.

\section{Electrophoresis}

The percentage distribution of the serum and colostrum proteins was determined from the analysis of the electrophoretic patterns using the 'classical' Tiselius apparatus (see Pierce, 1955).

The electrophoresis of serum proteins on paper was used for the separation of the various globulin components for serological tests.

Paper electrophoresis has been almost universally carried out using barbiturate buffers at $\mathrm{pH} 8 \cdot 6$. In order to separate the proteins on paper under buffer conditions similar to the 'classical' 'Tiselius method, phosphate buffers $\mathrm{KH}_{2} \mathrm{PO}_{4}$ and $\mathrm{Na}_{2} \mathrm{HPO}_{4}$, $I 0 \cdot 1, \mathrm{pH} 8 \cdot 0$, were used and found to be satisfactory (Fig. 3). This buffer is inexpensive and was changed after each run. The apparatus used was that described by Flynn \& de Mayo (1951). The levels in the electrode compartments were adjusted so that the effect of the electro-osmotic flow on protein migration was balanced by the hydrostatic effect. Strips of Whatman no. 1 filter-paper, each of $4 \mathrm{~cm}$. width, were moistened with buffer and placed in the apparatus. A current of $0.44 \mathrm{~mA} . / \mathrm{cm}$. width of paper was applied, and the system allowed to equilibrate for at least $1 \mathrm{hr}$. 
$0.04 \mathrm{ml}$. of undiluted serum was then applied to each strip and allowed to migrate for 17-20 hr. at room temperature. One or more strips were stained with Azocarmine (B) (Loeffler \& Wunderly, 1953) or bromphenol blue (Kunkel \& Tiselius, 1952), and by comparison with these strips the positions of the different protein components were marked on the unstained strips while they were still moist. The strips were cut up according to the positions of the different protein components, and the protein solution expressed for serological tests.

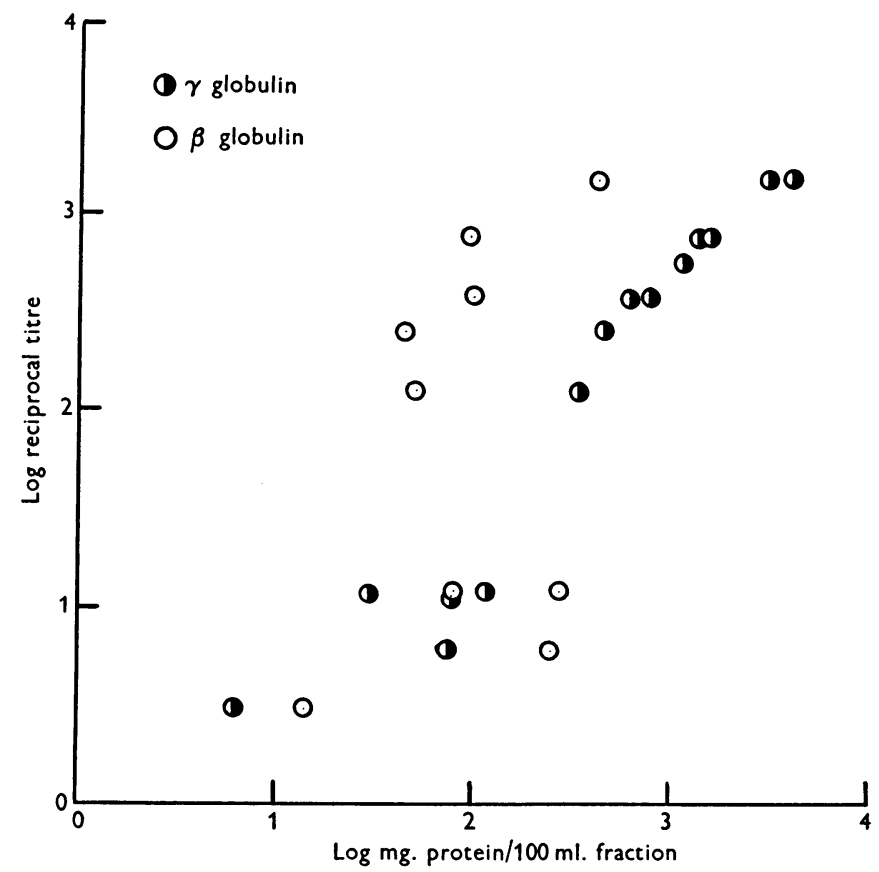

Fig. 1. The correlation of the titre to normal and induced agglutinins with mg. $\beta$ and $\gamma$ globulin/100 ml. of fractions prepared by $\mathrm{Na}_{2} \mathrm{SO}_{4}$, ether, and ethanol precipitation of bovine serum proteins.

\section{Serum protein estimations}

Protein concentrations were determined refractometrically for the Tiselius electrophoresis runs, and by a semi-micro-Kjeldahl method for the quantitative conversion of the electrophoretic analysis values (Pierce, 1955).

\section{EXPERIMENTAL RESULTS}

The identification of the major electrophoretic components in serum and colostrum associated with the normal and induced agglutinin activity

Bovine serum. Agglutination tests, using the $M$ and $B$ antigens (see p. 262) and protein fractions prepared from $B$ immune bovine sera, showed that there was no correlation between titre to the specific $B$ antigen and the concentration of either the albumin or $\alpha$ globulins. Fig. 1 shows the relationship between the $\gamma$ and $\beta$ globulins in $\mathrm{mg} . / 100 \mathrm{ml}$. and the titre to the $B$ antigen. The estimation of the correlation coefficient between the log of $\mathrm{mg}$. $\beta$ globulin $/ 100 \mathrm{ml}$. fraction, and log of the 
reciprocal of the titre was 0.287 on 7 degrees of freedom; which did not differ significantly from zero. The coefficient for the $\gamma$ globulin was 0.962 on 12 degrees of freedom, which differed significantly from zero. The difference between these estimated coefficients was significant at the $1 \%$ level and showed that a close relationship existed between the amount of $\gamma$ globulin and the titre, but not between the amount of $\beta$ globulin and the titre.

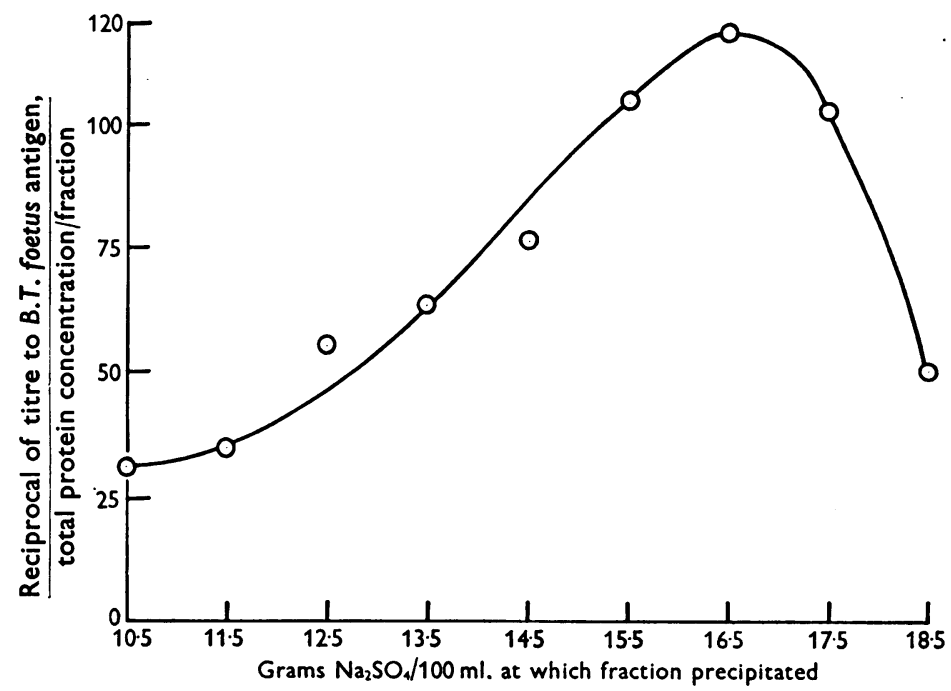

Fig. 2. The activity curve for normal agglutinins in fractions prepared by $\mathrm{Na}_{2} \mathrm{SO}_{4}$ fractionation of bovine serum.

The titre of the $M$ and $B$ antigens, the former responding mainly to the normal agglutinin and the latter to the normal and induced agglutinin suggested that the two agglutinins were to some extent differentially precipitated by $\mathrm{Na}_{2} \mathrm{SO}_{4}$ (Table 1). The precipitate at $12.5 \mathrm{~g} . \mathrm{Na}_{2} \mathrm{SO}_{4} / 100 \mathrm{ml}$. gave a much higher titre to the $B$ antigen than to the $M$, but the precipitate obtained at 17.5 and $18.5 \mathrm{~g} . \mathrm{Na}_{2} \mathrm{SO}_{4} / 100 \mathrm{ml}$. gave identical titres to $M$ and $B$ antigens; a response which would be expected if this agglutination were associated with normal agglutinin.

Table 1. The distribution of the electrophoretic components in mg. protein/100 $\mathrm{ml}$. in the different serum fractions, after immunization with B strain Trichomonas foetus antigen, and the agglutination titre using the $\mathrm{B}$ and $\mathrm{M}$ antigens

mg. protein $/ 100 \mathrm{ml}$.

fraction

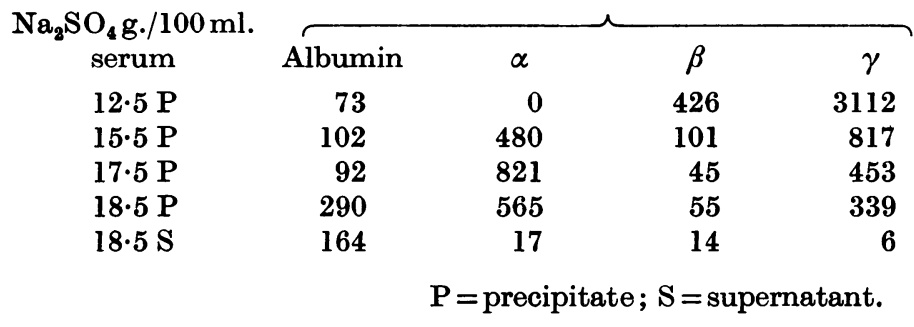

Agglutination end-point $T$. foetus strain in test

$\begin{array}{lc}\text { Belfast } & \text { Manley } \\ 1 / 1536 & 1 / 64 \\ 1 / 384 & 1 / 192 \\ 1 / 256 & 1 / 256 \\ 1 / 128 & 1 / 128 \\ <1 / 6 & <1 / 6\end{array}$


Fig. 2 shows the activity curve of the $B$ antigen against the normal serum protein fractions, and confirms the maximum precipitation of the normal agglutinin at salt concentrations between $15 \cdot 5-17 \cdot 5 \mathrm{~g} . \mathrm{Na}_{2} \mathrm{SO}_{4} / 100 \mathrm{ml}$.

Normal and immune serum proteins were separated electrophoretically on paper for agglutination tests. Both the normal and immune agglutinins were associated with the $\gamma$ globulin complex (Fig. 3).

Colostrum. The major component of the electrophoretic pattern of bovine colostral whey at parturition is a lacto-globulin with a low mobility, comprising approximately $70-75 \%$ of the total whey protein.

This lacto-globulin was separated by $\mathrm{Na}_{2} \mathrm{SO}_{4}$ fractionation as a single electrophoretic component (Pierce, 1955) and contains the normal and immune agglutinins.

\section{The evidence in support of the antibody nature of the normal agglutinin}

Non-specific agglutinating substances have been demonstrated in cattle serum (Gibson, 1930; Hess, $1953 a, b)$. Although the normal agglutinin titre in adult serum to the $M$ and $B$ strains is similar, and develops to both antigens in the young calf at approximately the same time (Kerr \& Robertson, 1954), absorption experiments showed that the normal agglutinin was specific to both $M$ amd $B$ strains (Table 2).

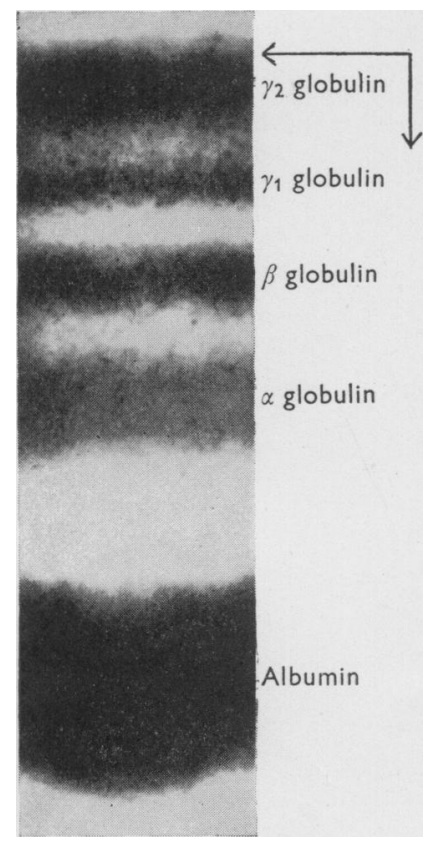

Fig. 3. The electrophorogram of bovine serum $(\mathrm{pH} 8 \cdot 0, I 0 \cdot 1$ phosphate buffer).

Table 2. The strain specificity of the normal agglutinin in adult cattle sera for M. and B Trichomonas foetus antigens

\begin{tabular}{|c|c|c|c|c|c|c|}
\hline \multirow[b]{2}{*}{ Serum } & \multirow[b]{2}{*}{ Antigen } & \multicolumn{5}{|c|}{ Final serum dilutions } \\
\hline & & $1 / 6$ & $1 / 12$ & $1 / 24$ & $1 / 48$ & $1 / 96$ \\
\hline Normal & $M$ & $+++(+)$ & +++ & ++ & $+(+)$ & + \\
\hline Normal & $B$ & $+++(+)$ & +++ & ++ & $+(+)$ & + \\
\hline \multirow[t]{2}{*}{ Belfast absorbed } & $M$ & +++ & ++ & + & tr. & - \\
\hline & $B$ & - & - & - & - & - \\
\hline \multirow{2}{*}{ Manley absorbed } & $M$ & - & - & - & - & - \\
\hline & $B$ & +++ & ++ & + & tr. & - \\
\hline \multirow[t]{2}{*}{ Saline controls } & $M$ & - & & & & \\
\hline & $B$ & - & & & & \\
\hline
\end{tabular}

Gibson (1930) showed that the true non-specific agglutinin was absorbed by charcoal. Kaolin, charcoal, and cellulose absorbent, however, did not significantly reduce the normal trichomonas agglutinin titre. These experiments confirmed the specificity of the normal agglutinin. 
Gibson (1930) also showed the presence in bovine serum of normal specific bacterial agglutinins which were not absorbed by charcoal. These resemble the normal trichomonas agglutinins in temperature of inactivation, $65^{\circ} \mathrm{C}$. for $10 \mathrm{~min}$., at which the induced agglutinins were unaffected.

The normal agglutinin appeared to be protein in nature since not only was it precipitated by protein precipitants, non-dialysable, and thermolabile, but it was also destroyed by digestion with trypsin $(1 \mathrm{~g} .10 \mathrm{ml}$. undiluted serum, for $17 \mathrm{hr}$. at $37^{\circ} \mathrm{C}$., $\mathrm{pH} 8 \cdot 0$ ).

The normal agglutinin in the presence of complement lysed $T$. foetus. This was difficult to demonstrate because the sera of vertebrates tested as a source of complement themselves contained some normal agglutinin and were therefore unsuitable. The agglutinin titres varied widely between species, but were relatively constant within them.

The calf before suckling, however, contains neither normal nor induced agglutinins, and was therefore a suitable source of complement. The validity of these experiments was confirmed using a more orthodox system. Inactivated normal adult bovine serum contains a natural agglutinin to human red blood corpuscles. This agglutinin with bovine complement in pre-colostral calf sera lysed human red blood corpuscles.

The normal agglutinin, therefore, although not possessing all the activities of the induced agglutinin and notably not sensitizing the animal to $T$. foetus antigen (Kerr $\&$ Robertson, 1946) agglutinates $T$. foetus, is specific to the particular strain, $M$ or $B$, and in the presence of complement acts as a lysin. It is thermolabile, is destroyed by a proteolytic enzyme and is precipitated with the $\gamma$ globulins.

\section{The serological and electrophoretic examination of sera from 'in-calf' cattle approaching calving}

The intramuscular injection of graded doses of freeze-dried $B$ antigen into two 'in-calf' cattle ( 1 and 2$)$ during the penultimate month before calving stimulated induced agglutinins and an increase of $\gamma$ globulin of up to $10 \%$ of the total protein.

After the initial increase in $\gamma$ globulin in animal 1, the electrophoretic analysis showed a gradual decrease which continued regardless of further antigen injections and reached a value below the pre-immunization level immediately before calving (Fig. 4). The $\gamma$ globulin level in animal 2 also showed a decline as the animal approached calving (Fig. 4).

Because the changes in the serum proteins of these two animals were complicated by the antigen injections, serum samples from two normal 'in calf' cattle were examined over the same period. In both of them the $\gamma$ globulin again decreased as they approached parturition (Fig. 5). All four animals therefore showed a decline in the percentage $\gamma$ globulin values starting about 20-30 days before calving. The total serum protein values usually declined before parturition, so that the quantitative fall in the $\gamma$ globulin was greater than the percentage fall. 
The serological and electrophoretic examination of calf sera from birth onwards

Calves fed colostrum containing normal and induced agglutinins. Fig. 6 shows the fall in the normal (Fig. 6a) or normal and induced (Fig. 6b) passively acquired maternal agglutinins in calves following the suckling of colostrum. The rate of elimination of passive antibody in adult animals is logarithmic, and it was shown that this was also true in the young calf acquiring passive globulins by ingestion.

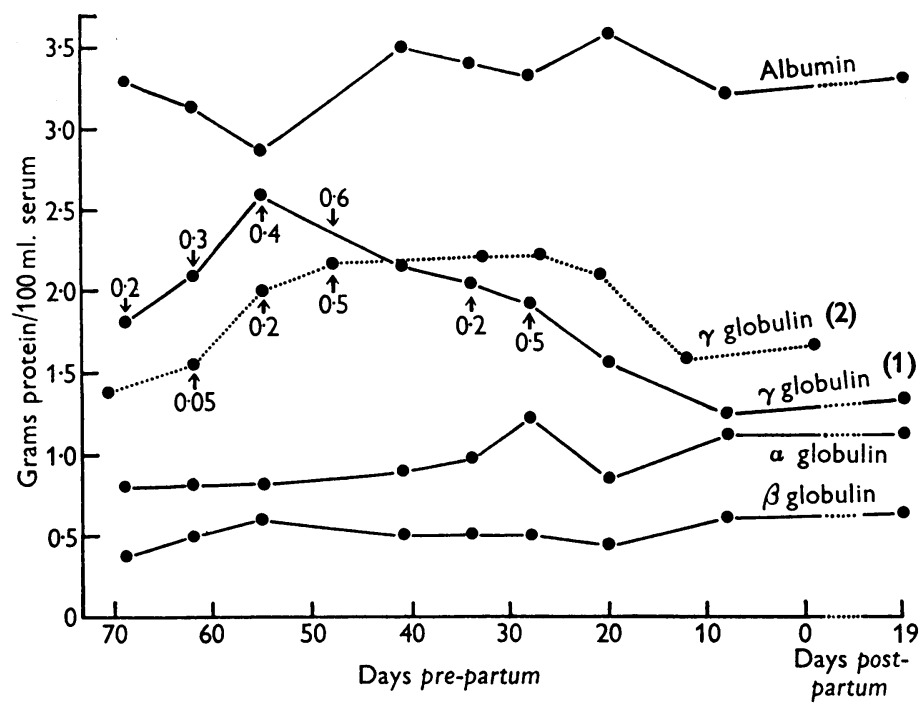

Fig. 4. The sequence of changes in the electrophoretic components of two 'in-calf' cattle $(1,2)$ approaching calving, and during immunization with $T$. foetus antigen (g. dry wt.).

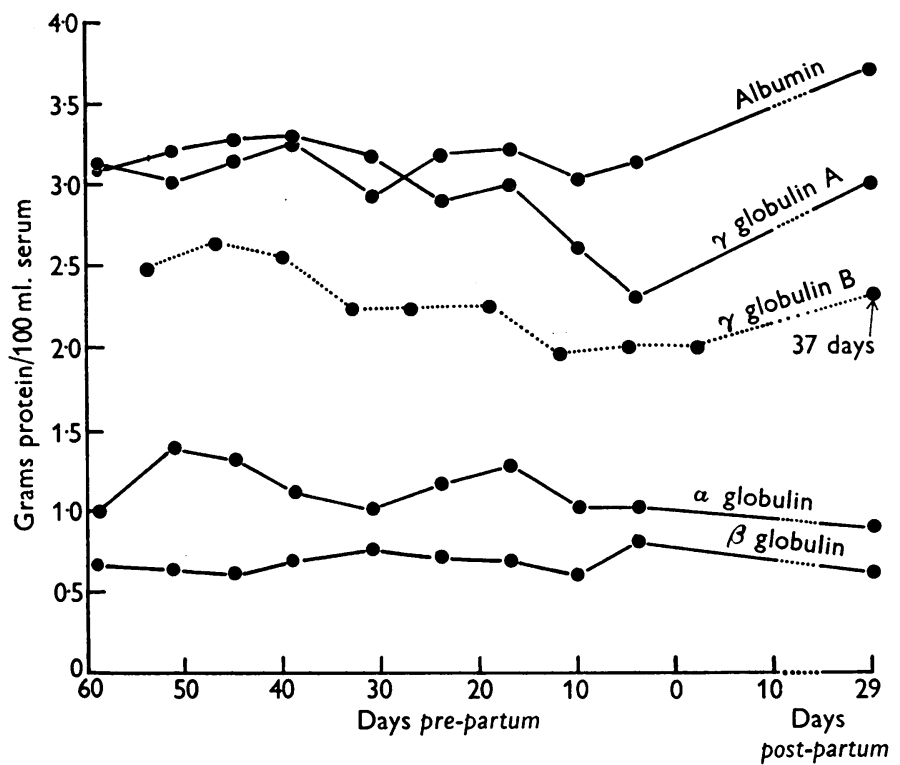

Fig. 5. The sequence of changes in the electrophoretic components of sera from two 'in-calf' cattle (A, B) approaching calving. 
In those calves suckling normal colostrum and acquiring a low titre there was a period following the elimination of the passive agglutinin, and before the autogenous production of normal agglutinin, when no agglutinins to $T$. foetus were detected in the serum. Calves suckling colostrum from immunized mothers,
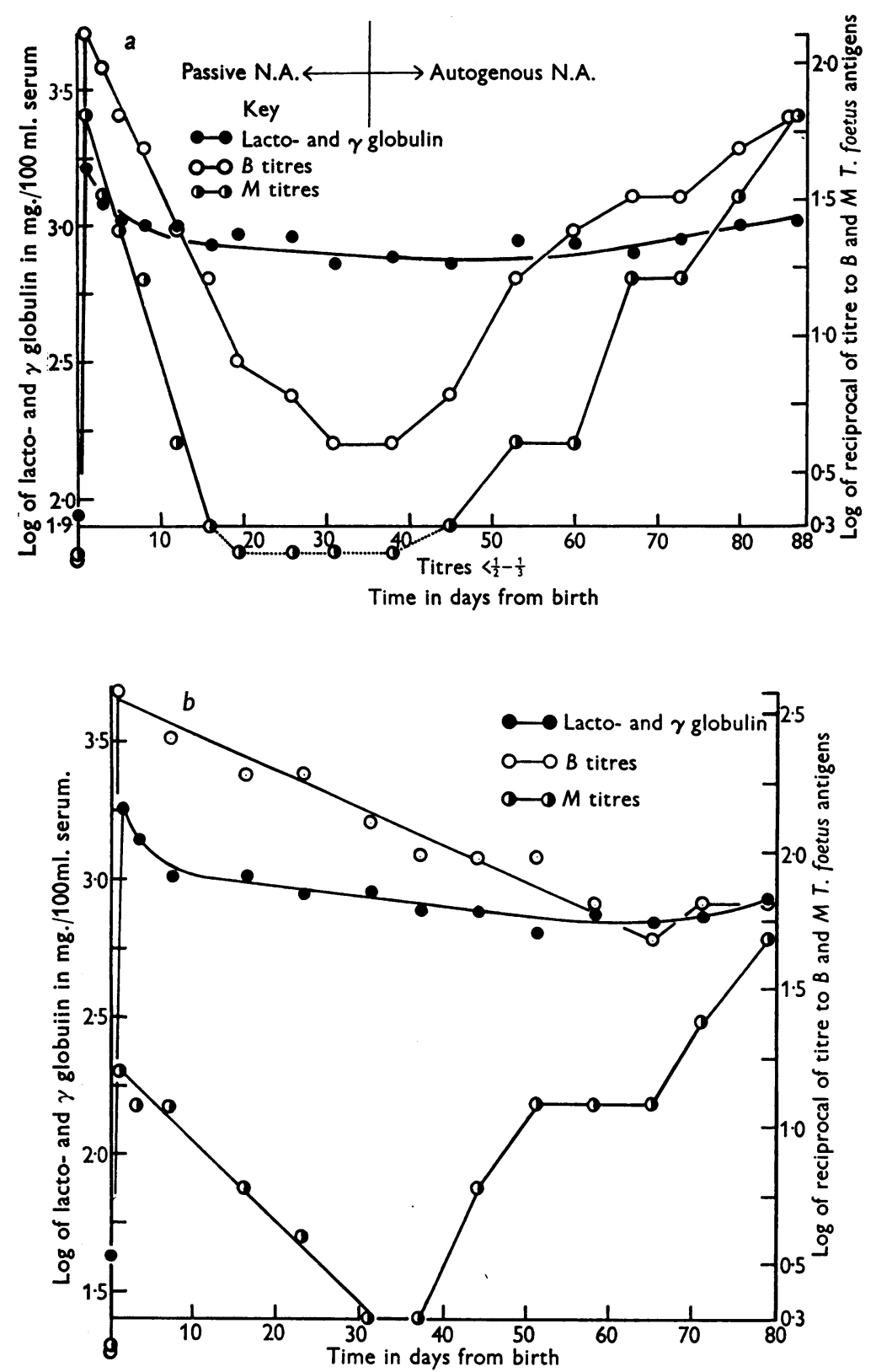

Fig. 6. The decline in titre of the passive agglutinin and the subsequent rise in the autogenous normal agglutinin of two colostrum-fed calves. (a) Calf-fed normal colostrum containing normal agglutinin, and $(b)$ calf-fed colostrum containing normal, and induced $B$ agglutinin. The electrophoretic analyses of the changes in the $\gamma$ and lacto-globulins are also shown. 
however, had a higher initial titre, and before this had disappeared completely autogenous normal agglutinin was frequently made (Fig. $6 b$ ).

The rate of elimination of normal and induced agglutinins passively acquired by the calf was logarithmic. However, the log values of the lacto-globulin showed a rapid falling-off in the rate of elimination due to the autogenous production of $\gamma$ globulin (Pierce, 1955) (Fig. 6a, $b$ ).

The autogenous normal agglutinins were first detected between 30 and 60 days after birth (except one at 16 days). These findings confirm the observations of Kerr \& Robertson (1954).

The normal agglutinin to $T$. foetus in adult cattle serum has a titre between $1 / 48$ and 1/96. After immunization the induced homologous agglutinin titre may rise to $1 / 3000$ or more and if the immunization course is not too long, is $M$ or $B$ specific. Colostral whey from immunized cattle tested for normal and induced agglutinins showed no selective concentration of induced agglutinin over the normal agglutinin when compared with normal and induced titre in the dam prior to calving and during immunization. Both the normal and induced agglutinins therefore were transferred passively by the colostrum from dam to calf.

Deprived calves. The development of the normal autogenous agglutinin can be studied more easily in calves partially deprived of colostrum, because only a small amount of lacto-globulin is absorbed and the acquired passive titres are low and soon eliminated.

The initial autogenous production of the normal agglutinin in calves partially deprived of colostral protein occurred between the 30th and 50th days, at a similar age to the calves in the colostrum-fed group. There was no correlation between the autogenous development of any one $\gamma$ globulin component and the detection of the autogenous natural agglutinin.

One calf showed an exceptionally rapid autogenous $\gamma$ globulin build-up, reaching a low adult level of $27 \%$ of the total protein by the 42nd day (Fig. 7). Although three $\gamma$ globulin components (Pierce, 1955) could be detected from the 28th day there was no detectable autogenous normal agglutinin until the 50th day. As the normal agglutinin titre rose to the adult level of $1 / 96$ on the 78th day, so the total $\gamma$ globulin decreased from $31 \%$ on the 50th day to $18 \%$ of total protein on the 78 th day (Fig. $7 b$ ).

The electrophoretic results show that young calves which have produced the three main $\gamma$ globulin components characteristic of adult sera may not necessarily have developed the normal agglutinins. This emphasizes the specificity of the reaction and that the organisms are not agglutinated by a non-specific serum protein effect.

\section{Calves fed colostrum and actively immunized with Trichomonas foetus antigen during very early life}

Sera obtained from a research being carried out by Kerr \& Robertson on the response of very young calves to $T$. foetus antigen were kindly placed at the disposal of the author. Kerr \& Robertson had injected a total of $2 \mathrm{~g}$. of freeze-dried $B$ antigen intramuscularly into two calves within the first 23 days after birth. The 
agglutination tests confirmed those of Kerr \& Robertson (1954). The passive normal agglutinin titre to both $B$ and $M$ strains declined during the period of antigen injections and a rise in titre to both $M$ and $B$ strains occurred between the 30th and 50th days as in the calves in the previous two sections (Fig. 8a, b).

The material injected into these calves was shown by Kerr \& Robertson (1954) to be antigenic, and to have been injected in a quantity considerably greater than that required to elicit an appreciable immune response in an adult animal.
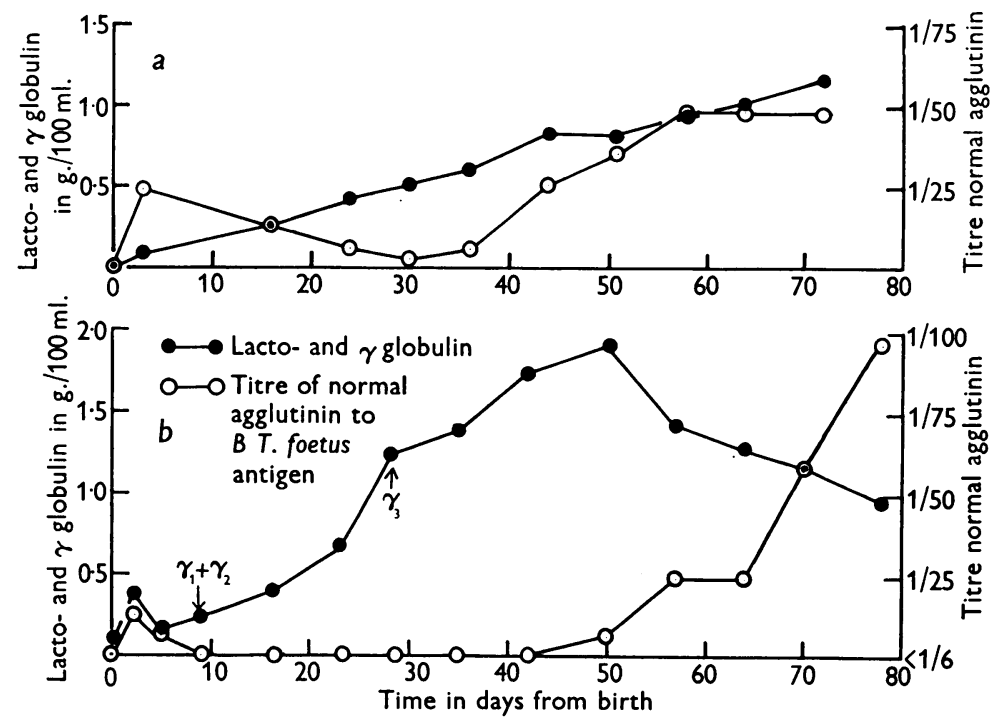

Fig. 7. The low passive titre of two colostrum deprived calves $(a)$ and $(b)$, and the subsequent rise in autogenous normal agglutinin. The electrophoretic analyses of the changes in the $\gamma$ globulin are also shown.

The times of injection of antigen and production of agglutinin were not related. The titre developed by the two calves did not exceed that of the normal agglutinin in adult bovine serum (1/48). The calves failed to respond therefore with the production of induced agglutinins, although both developed autogenous normal agglutinins.

The electrophoretic results showed that 2 days after the ingestion of colostrum both calves had acquired passive lactoglobulin, one calf (H 9) considerably more than the other (P. 10C). Both calves subsequently showed evidence of the autogenous production of $\gamma$ globulin, first by an apparent slowing in the rate of elimination of the passive lacto-globulin, secondly by a subsequent increase in the $\gamma$ globulin, and thirdly by the electrophoretic evidence of the adult $\gamma$ globulin components developing as the lacto-globulin was eliminated. Calf $\mathrm{H} .9$ showed a marked quantitative increase in total $\gamma$ globulin by the 44th day and the three $\gamma$ globulin components could be detected. In calf $\mathrm{P}$. $10 \mathrm{C}$ the autogenous production and rise in $\gamma$ globulin was less pronounced. However, $\gamma_{1}$ and $\gamma_{2}$ globulins could be distinguished by the $23 \mathrm{rd}$ day. The calves therefore were producing autogenous $\gamma$ globulin and autogenous normal agglutinins, but regardless of the 
presence in their tissues of a foreign protein of known antigenicity did not produce detectable induced agglutinins.

In further experiments on these two calves (H. 9, P. 10C) Kerr \& Robertson (1954) showed that their capacity to respond to further injections of $T$. foetus antigen was still seriously impaired at 12 months of age.

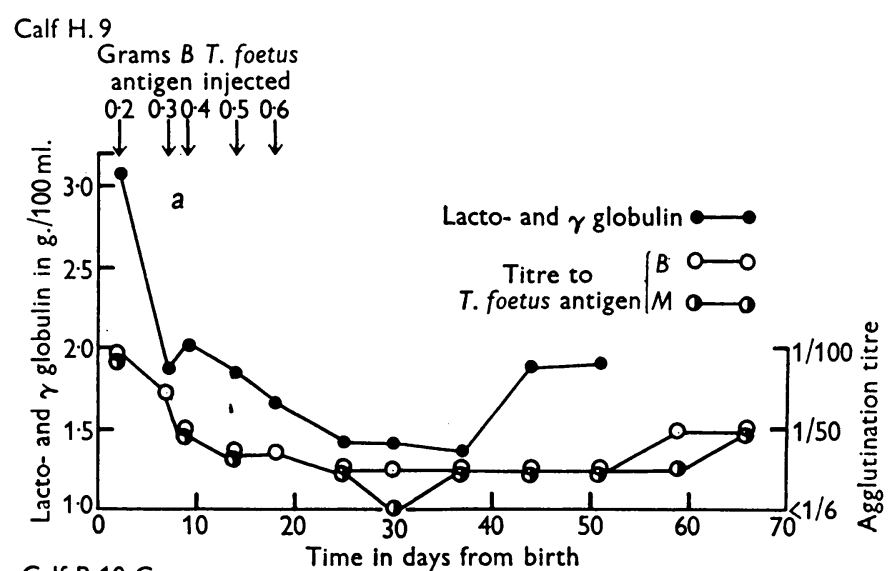

Calf P.10 C.

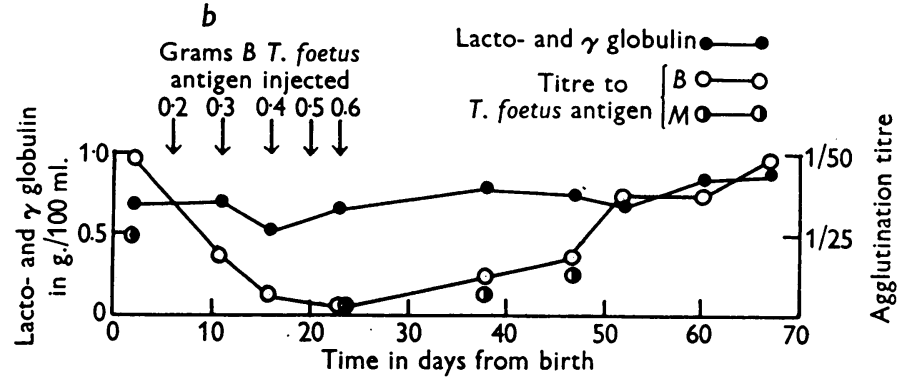

Fig. 8. The decline in titre of the passive normal agglutinin to $M$ and $B$ antigens, and the rise in the autogenous normal agglutinins of two immunized calves $(a) \mathrm{H} .9$ and $(b)$ P. 10C. The electrophoretic analyses of the changes in the $\gamma$ and lacto-globulins are also shown. (See Kerr \& Robertson (1954).)

\section{DISCUSSION}

There is a probability that many normal agglutinins are specific residua from earlier infections, subclinical infections, or carrier states either with the specific test organism or with one containing a shared antigen. Commensal or symbiotic organisms in the host may share antigens with the test organism, and antigenic material may gain access via the reproductive, respiratory, or alimentary tract or the dermis, and stimulate the production of apparently normal agglutinins.

Peters (1940), for example, has shown that in localities in which a specific infection was endemic there was a higher incidence of apparently normal antibodies to the prevailing pathogen. Similarly, Zingher $(1923,1924)$ showed that there was a gradual increase in Schick (diphtheria) and Dick (scarlet fever) negative reactors with increasing age; a rapid increase occurring at the beginning of schooling. Trichomoniasis is a strictly venereal disease in cattle, so that production of the 
normal agglutinin between 1 and 2 months of age was not stimulated by the specific pathogen. There are, however, many protozoa, such as T. ruminantium, which inhabit the alimentary tract of cattle, which might share identical or closely related antigens with $T$. foetus, and might therefore stimulate the normal agglutinin. If such an explanation were correct it is difficult to account for the regularity in the time of production of the normal agglutinin, the uniform occurrence and constant level of the titre during adult life, and the high degree of specificity which the normal agglutinin to $T$. foetus has been shown to possess. Normal agglutinins to $T$. foetus, unlike the induced agglutinins, do not cause dermal or uterine sensitivity (Kerr \& Robertson, 1946, 1953) and adult cattle which have developed the normal agglutinin show a typical primary response to the injection of $T$. foetus antigen. The thermostability and the salting out characteristics of the two agglutinins are different. Finally, although very young animals have been shown to be unresponsive to antigenic stimulus, and in the present experiments gave no response to considerable quantities of $T$. foetus antigen, the calves, nevertheless, with regard to time and titre developed the normal agglutinin in the usual way. From these experiments it appears that the two $T$. foetus agglutinins are quite different in character.

The normal agglutinin to $T$. foetus, however, should be compared with the natural bacterial agglutinins studied by Gibson (1930).

Gibson tested different vertebrate sera against various bacterial suspensions and showed that the degree of agglutination was dependent upon the species from which the sera were derived rather than upon the particular antigen used. Ox sera were found to have the highest titre and rabbit, guinea-pig and rat the lowest; a similar relationship has been observed with $T$. foetus (Pierce, 1954). Gibson (1930) showed that there were two types of normal agglutinin, a true non-specific agglutinin which could be removed with charcoal, and a highly specific normal agglutinin which would appear to be very similar to normal $T$. foetus agglutinin. The temperatures of inactivation of the bacterial and $T$. foetus normal agglutinins are similar $\left(60-65^{\circ} \mathrm{C}\right.$.) and are above that for complement and below that for induced agglutinins. Also, the bacterial and $T$. foetus normal and induced agglutinins could be separated to some extent with protein precipitants.

Kerr \& Robertson (1954) showed that both the normal and the induced agglutinins were transferred to the calf in the colostrum, and that they were subsequently eliminated logarithmically. They are replaced by autogenous normal agglutinins between the 30th and 60th days. The present experiments confirm these observations and show that both the normal and induced agglutinins are associated with the $\gamma$ globulins in the serum and with the lacto-globulin in colostrum. The electrophoretic analyses showed that calves developed autogenous $\gamma$ globulin within a few days of birth, and that the two main $\gamma$ globulin components (and occasionally a third component) were frequently developed before normal agglutinins could be detected. It was surprising, therefore, that calves into which antigen was injected before they were 30 days old, and which were producing $\gamma$ globulin and subsequently the normal autogenous agglutinin did not respond with the production of induced agglutinin. Similarly, Hanan \& Oyama (1954) showed that very young 
rabbits failed to respond to antigenic stimulation although producing $\gamma$ globulin, and that these rabbits when mature were still unresponsive.

On the evidence presented it appears that there are differences between the normal and the induced agglutinin. These suggest that the normal agglutinin is not induced by an exogenous antigen, and that it may be one of a number of natural antibodies which are unmodified $\gamma$ globulin molecules (primary units) having an 'accidental' configuration complementary to the antigen $(T$. foetus) (see Burnet \& Fenner, 1949).

\section{SUMMARY}

1. The lacto-globulin in bovine colostral whey, and the $\gamma$ globulin in the serum contain the normal and induced agglutinins to the protozoon Trichomonas foetus.

2. A decline in $\gamma$ globulin in sera from cattle approaching calving may be associated with the concentration of the lacto-globulin in the udder.

3. The elimination of the passive normal and induced agglutinins acquired by the neonatal calf was logarithmic. The autogenous production of $\gamma$ globulin by the calf occurred soon after birth, resulting in an apparent decline in the rate of elimination of the lacto-globulins.

4. The autogenous production of $\gamma$ globulin was not necessarily accompanied by that of detectable normal agglutinin.

5. Calves injected with $T$. foetus antigen within the first 3 weeks of life, and in which there was evidence of autogenous $\gamma$ globulin, developed normal autogenous but not induced agglutinins.

6. Calves which received colostrum containing maternal induced and normal agglutinins, calves partially deprived of colostrum, and calves immunized in early life, produced the normal autogenous agglutinin between the 30th and 60th days, reaching the normal adult titre of $1 / 48-1 / 96$.

7. The properties of the normal agglutinins were investigated. They possess some characteristics significantly different from those of the induced agglutinins. These suggested that the normal agglutinins were $\gamma$ globulin molecules with an 'accidental' genetic configuration complementary to $T$. foetus.

The author wishes to thank Dr M. Robertson, F.R.S., and Sir Alan Drury, F.R.S. for their interest and encouragement during the course of this work, and Dr R. C. Campbell for the statistical analysis.

\section{REFERENCES}

Aschaffenburg, R. (1949). Brit. J. Nutr. 3, 200.

Burnet, F. M. \& Fenner, F. (1949). The Production of Antibodies. Australia: Melbourne.

Comline, R. S., Roberts, H. E. \& Titchen, D. A. (1951 a). Nature, Lond., 167, 561.

Comline, R. S., Roberts, H. E. \& Titchen, D. A. (1951b). Nature, Lond., 168, 84.

Flynn, F. V. \& DE Mayo, P. (1951). Lancet, ii, 235.

Grbson, H. J. (1930). J. Hyg., Camb., 30, 337.

HaNAN, R. \& Oyama, J. (1954). J. Immunol. 73, 49.

Hess, E. L. \& Deutsch, H. F. (1948). J. Amer. chem. Soc. 70, 84.

Hess, E. L. \& Deutsch, H. F. (1949). J. Amer. chem. Soc. 71, 1376. 
Hess, W. R. (1953a). Amer. J. vet. Res. 14, 192.

Hess, W. R. (1953b). Amer. J. vet. Res. 14, 195.

KEKWICK, R. A. (1940). Biochem. J. 34, 1248.

Kekwick, R. A. \& Mackay, M. E. (1954). Spec. Rep. Ser. med. Res. Coun, Lond., no. 286.

Kekwick, R. A. \& ReCord, B. R. (1941). Brit. J. exp. Path. 22, 29.

KERR, W. R. \& Robertson, M. (1941). Vet. J. 97, 351.

Kerr, W. R. \& Robertson, M. (1943). J. comp. Path. 53, 280.

KerR, W. R. \& Robertson, M. (1945). Vet. Rec. 57, 221.

Kerr, W. R. \& Robertson, M. (1946). J. comp. Path. 56, 38.

KerR, W. R. \& Robertson, M. (1953). J. Hyg., Camb., 51, 405.

KerR, W. R. \& Robertson, M. (1954). J. Hyg., Camb., 52, 253.

Kunkel, H. G. \& Tiselius, A. (1952). J. gen. Physiol. 35, 89.

Loeffrler, W. \& Wunderly, C. (1953). J. clin. Path. 6, 282.

Peters, B. A. (1940). Publ. Hlth, Lond., 53, 215.

Pierce, A. E. (1947). Lab. J. 8, 238.

Pierce, A. E. (1954). Ph.D. Thesis, London University.

Pierce, A. E. (1955). J. Hyg., Camb., 53, 247.

Zingher, A. (1923). Amer. J. Dis. Child. 25, 392.

ZiNGHer, A. (1924). Amer. J. publ. Hlth, 14, 955.

(MS. received for publication 7. x. 54) 